J. Dairy Sci. 92:563-570

doi:10.3168/jds.2008-1495

(c) American Dairy Science Association, 2009.

\title{
Developmental competence of bovine embryos from heat-stressed ova
}

\author{
J. L. Edwards, ${ }^{1}$ A. N. Bogart, L. A. Rispoli, A. M. Saxton, and F. N. Schrick \\ The University of Tennessee, Institute of Agriculture, Tennessee Agricultural Experiment Station, \\ Department of Animal Science, Knoxville 37996-4574
}

\section{ABSTRACT}

Because multiple ovulation embryo transfer procedures are occasionally performed in cows experiencing heat stress, the goal of this study was to assess the developmental competence of otherwise morphologically normal embryos from heat-stressed ova. To this end, the ability of compact morulae from heat-stressed and non-heat-stressed bovine ova to undergo blastocyst development after culture at 38.5 or $41.0^{\circ} \mathrm{C}$ was examined. It was hypothesized that heat-induced perturbations in the ooplasm carry over to increase the susceptibility of the preattachment embryo to heat stress. Initially, ova were matured at 38.5 or $41.0^{\circ} \mathrm{C}$. The consequences of heat stress did not include altered cleavage, but did reduce the proportion of 8- to 16-cell-stage embryos (55.3 vs. $50.6 \% ; \mathrm{SEM} \pm 1.9$ ). Although proportionately fewer, compact morulae from heat-stressed ova were equivalent in quality to those from non-heat-stressed ova (2.1 and 2.1; SEM =0.04). Culture of compact morulae from non-heat-stressed ova at $41.0^{\circ} \mathrm{C}$ did not affect blastocyst development (71.9 and $71.5 \%$; SEM = 3.0). Furthermore, the development of compact morulae from heat-stressed ova was similar to that of non-heatstressed ova after culture at $38.5^{\circ} \mathrm{C}$ (68.2 vs. 71.9 and $71.5 \%$; SEM $=3.0$ ). However, blastocyst development was reduced when compact morulae from heat-stressed ova were cultured at $41.0^{\circ} \mathrm{C}(62.3$ vs. $71.9,71.5$ and $68.2 ;$ SEM $=3.1$ ). In summary, reduced compaction rates of heat-stressed ova explained in part why fewer develop to the blastocyst stage after fertilization. The thermolability of the few embryos that develop from otherwise developmentally challenged ova emphasizes the importance of minimizing exposure to stressor(s) during oocyte maturation.

Key words: heat stress, thermolability, oocyte, embryo

Received June 27, 2008.

Accepted October 6, 2008.

${ }^{1}$ Corresponding author: jedwards@utk.edu

\section{INTRODUCTION}

Infertility coupled with reduced milk production during summer heat stress is an important economic problem for the dairy industry. As the temperaturehumidity index approaches 72 , lactating dairy cows lose the ability to maintain body temperature (Armstrong, 1994). Rectal temperatures parallel those occurring in utero (Gwazdauskas et al., 1973) and may reach or exceed $41^{\circ} \mathrm{C}$ (Monty and Wolff, 1974; Roman-Ponce et al., 1977; Ealy et al., 1993). Heat-induced hyperthermia is not without consequence, because Ulberg and Burfening (1967) observed a decrease in pregnancy rate of approximately $25 \%$ for every $1{ }^{\circ} \mathrm{C}$ elevation in rectal temperature. Reductions in cow fertility are problematic when heat stress occurs at or near estrus (Stott and Williams, 1962; Gwazdauskas et al., 1973) and are due in large part to the direct effects of elevated body temperature to compromise the maturing ovum. In support of this, heat-induced increases in rectal temperatures $\left(\geq 41.0^{\circ} \mathrm{C}\right)$ during estrus (i.e., time period when the ovum within the Graafian follicle has resumed meiosis and is progressing to metaphase II) reduces embryonic viability (Putney et al., 1989). Furthermore, direct application of heat stress to maturing ova typically reduces embryonic development by 42 to $65 \%$ (Edwards and Hansen, 1996; Edwards et al., 2005; Schrock et al., 2007), which is consistent with the consequence of exposing maturing ova to elevated body temperature.

Although the magnitude of the effect depends on the severity and duration of heat stress (Edwards and Hansen, 1996; Payton et al., 2004), the proportion of heat-stressed ova that develop into morphologically normal embryos (i.e., compact morulae and blastocysts), despite exposure to hostile conditions while undergoing maturation in vitro (Schrock et al., 2007) or in vivo after superovulation (Putney et al., 1989), is remarkable. Because the pregnancy rates of dairy cows are more often proportionately reduced rather than zero, it is plausible for a subset of ova to be "thermotolerant" and contribute to the formation of a morphologically normal embryo competent for further development. Nevertheless, widespread effects of heat stress occur in the ooplasm after direct application [e.g., alterations 
in de novo synthesis of proteins (Edwards and Hansen, 1996, 1997), changes in transcript abundance (J. Edwards, unpublished data), possible increases in free radicals (Lawrence et al., 2004), and factors involved in apoptosis (Roth and Hansen, 2004)]. The heatstressed ovum contributes half of the genetic material and $>99 \%$ of cytoplasm to the early embryo; thus, it is plausible that some negative effects carry over to the otherwise morphologically normal embryos, impairing further development. In support of this, Rutigliano et al. (2008) reported that dairy cows exposed to heat stress during AI may lose their pregnancy compared with those not exposed to heat stress. Still, low numbers of heat-stressed dairy cows in that study limit further inference.

Because multiple-ovulation embryo transfer procedures are occasionally performed in cows experiencing heat stress, a major goal was to assess the developmental competence of otherwise morphologically normal embryos from heat-stressed ova. The experimental approach was to evaluate the ability of compact morulae from non-heat-stressed or heat-stressed ova to undergo blastocyst development after culture at a thermoneutral or physiologically relevant elevated temperature (i.e., $41.0^{\circ} \mathrm{C}$; Monty and Wolff, 1974; Roman-Ponce et al., 1977; Ealy et al., 1993) because cows experience heat stress not only during estrus, but on subsequent day(s) as well. Preference for the use of compact morulae was based on previous findings demonstrating that this embryonic stage was tolerant of in vivo (rectal temperatures $\geq 41.0^{\circ} \mathrm{C}$; Ealy et al., 1993) and in vitro $\left(41.0^{\circ} \mathrm{C}\right.$; Ealy et al., 1995; Edwards and Hansen, 1997) exposure to heat stress.

\section{MATERIALS AND METHODS}

\section{Materials}

All chemicals were purchased from Sigma Chemical Company (St. Louis, MO) unless otherwise noted. Modified Tyrode's albumin lactate pyruvate (TALP) base-media [HEPES-TALP, in vitro fertilization (IVF)-TALP, and Sperm-TALP; Parrish et al., 1988] were prepared in the laboratory. Potassium simplex optimized medium was prepared (Biggers et al., 2000), but modified to contain $0.5 \%$ BSA, $10 \mathrm{~m} M$ glycine, $1 \mathrm{~m} M$ L-glutamine, $1 \times$ nonessential AA, $50 \mathrm{U} / \mathrm{mL}$ of penicillin, and $50 \mu \mathrm{g} / \mathrm{mL}$ of streptomycin (mKSOM). Medium-199, penicillin-streptomycin, and gentamicin were purchased from Invitrogen (Carlsbad, CA). Folltropin- $\mathrm{V}$ and fetal bovine serum were obtained from Vetrepharm Canada Inc. (London, Ontario, Canada) and BioWhittaker (Walkersville, MD), respectively.
Frozen semen was generously provided by Ultimate Genetics Inc. (Wheelock, TX).

\section{General Methods for In Vitro Production of Embryos}

In vitro production of embryos was performed (Edwards et al., 2005; Schrock et al., 2007). Briefly, cumulus-oocyte complexes (COC) were harvested from antral follicles (approximately 3 to $10 \mathrm{~mm}$ ) on abattoirderived ovaries (Brown Packing Co. Inc., Gaffney, SC). Only COC with a dark, evenly granulated ooplasm and compact cumulus were matured in groups of 45 to 50 in $500 \mu \mathrm{L}$ of maturation medium (Medium-199 containing Earle's salts, $10 \%$ fetal bovine serum, $50.0 \mu \mathrm{g} / \mathrm{mL}$ of gentamicin, $5.0 \mu \mathrm{g} / \mathrm{mL}$ of FSH, $0.2 \mathrm{mM}$ Na pyruvate, and $2 \mathrm{mM}$ L-glutamine) in a $5.5 \% \mathrm{CO}_{2}$ humidified environment. After $24 \mathrm{~h}$ of in vitro maturation (IVM), IVF was performed with Percoll-prepared frozen-thawed semen $(500,000$ motile sperm $/ \mathrm{mL})$. Pooled semen from 2 bulls was used for IVF in each experimental replicate. In total, 5 different bull combinations were used. Putative zygotes $(\mathbf{P Z})$ were denuded of cumulus and associated spermatozoa by vortexing for 5 min in HEPES-TALP containing $0.3 \mathrm{mg} / \mathrm{mL}$ of hyaluronidase. Thereafter, PZ were cultured in groups of 25 to 35 per $500 \mu \mathrm{L}$ of mKSOM at $38.5^{\circ} \mathrm{C}, 5.5 \% \mathrm{CO}_{2}, 7.0 \% \mathrm{O}_{2}$, and $87.5 \% \mathrm{~N}_{2}$ in a humidified environment.

\section{Experimental Design and Endpoints}

Initially, COC were matured at 38.5 or $41.0^{\circ} \mathrm{C}$ (heat stress was applied during the first $12 \mathrm{~h}$ of IVM, and ova were then matured at $38.5^{\circ} \mathrm{C}$; Figure 1). At approximately 13 to $17 \mathrm{~h}$ post-IVF (hpi), the number of $\mathrm{PZ}$ recovered as well as those that had visibly lysed after denuding was recorded. Ability of PZ to cleave was assessed at 69 to $72 \mathrm{hpi}$ by recording the number of 1-, 2-, 4-, and 8- to 16-cell embryos. The ability of embryos to undergo compaction was evaluated at 138 to $144 \mathrm{hpi}$. At this time, an evaluator uninformed of treatment assigned and recorded quality scores of the compacted embryos (Robertson and Nelson, 1998).

Compact morulae (combination of quality scores ranging from 1 to 3 ) were kept separate according to origin (i.e., ova undergoing IVM at 38.5 or $41.0^{\circ} \mathrm{C}$ ), then randomly and evenly distributed to culture at 38.5 or $41.0^{\circ} \mathrm{C}$ (heat stress was applied for $12 \mathrm{~h}$, embryos were then cultured at $38.5^{\circ} \mathrm{C}$; Figure 1). The ability of compact morulae to undergo blastocyst development was assessed at 184 to $211 \mathrm{hpi}$. An evaluator uninformed of treatment assigned stage and quality scores according to the method of Robertson and Nelson (1998). 


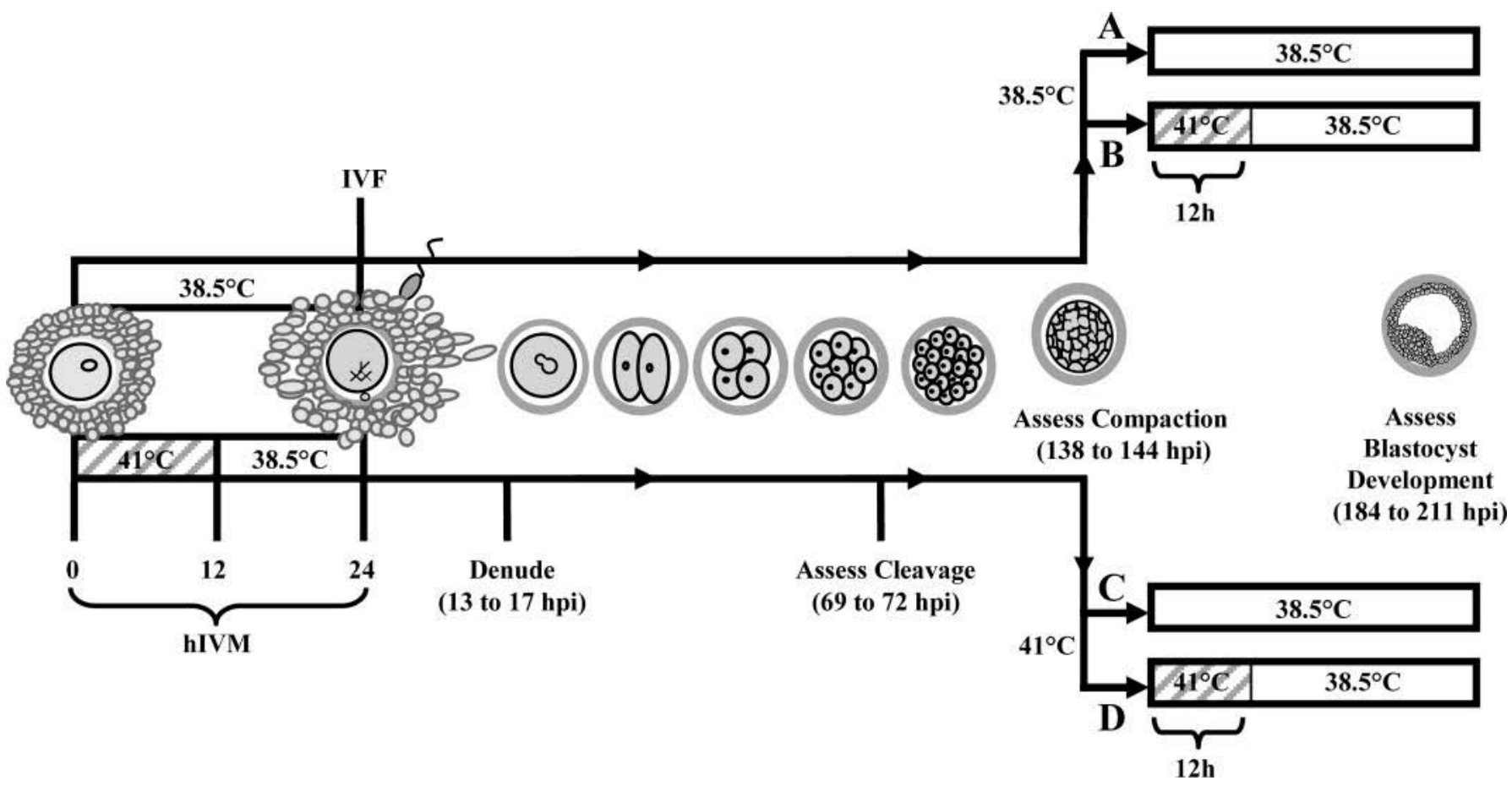

Figure 1. Schematic representation of experimental design and end points. Initially, cumulus-oocyte complexes were matured at 38.5 or $41.0^{\circ} \mathrm{C}$ [heat stress was applied during the first $12 \mathrm{~h}$ of in vitro maturation (hIVM); ova were then matured at $38.5^{\circ} \mathrm{C}$. After a total of $24 \mathrm{hIVM}$, cumulus-oocyte complexes underwent in vitro fertilization (IVF). At 13 to $17 \mathrm{~h}$ post IVF (hpi) ova were denuded of associated cumulus and spermatozoa; the number recovered as well as those that had visibly lysed was recorded. The ability of presumptive zygotes to undergo cleavage and compaction was assessed at 69 to 72 and 138 to $144 \mathrm{hpi}$, respectively. Compact morulae were kept separate according to origin (i.e., from ova undergoing in vitro maturation at 38.5 or $41.0^{\circ} \mathrm{C}$ ), then randomly and evenly distributed to culture at 38.5 or $41.0^{\circ} \mathrm{C}$ (heat stress was applied for $12 \mathrm{~h}$; embryos were then cultured at $38.5^{\circ} \mathrm{C}$ ). The ability of compact morulae to undergo blastocyst development was assessed at 184 to 211 hpi.

\section{Statistical Analyses}

In total, this experiment was replicated on 20 different occasions (i.e., different days of oocyte collection). The developmental competence of ova collected on each occasion was determined in retrospect by calculating the proportion of blastocysts from non-heat-stressed ova. In experimental replicates in which blastocyst development exceeded 20\% ( $\mathrm{n}=15$ occasions), ova were deemed developmentally competent. In instances in which blastocyst development of ova was $<20 \%$ (n $=5$ occasions), ova were deemed developmentally challenged (actual range was 12.0 to $14.7 \%$ ). To obviate concerns regarding the interpretation of results from ova differing in developmental competence, data from developmentally competent versus challenged ova were analyzed and reported separately. Doing so was warranted because Livingston et al. (2004) noted in previous efforts that the responsiveness of ova to changes in culture environment differed depending on the level of developmental competence. In that study, retinol administration was beneficial only when added to otherwise developmentally challenged ova (i.e., blastocyst development was $<20 \%$ ).
To evaluate the consequences of maturing ova at 38.5 or $41.0^{\circ} \mathrm{C}$ on various aspects of embryo development (i.e., cleavage through compaction), data were analyzed as a randomized block design, blocking on day of oocyte collection, by using generalized linear mixed models (PROC GLIMMIX; SAS 9.1, SAS Inst. Inc., Cary, NC). In all cases, correction for overdispersion was required (Littell et al., 2006). Treatment differences were determined by using protected least significant differences and were reported as least squares means \pm standard error of the means by using the inverse link option. The development of compact morulae from heat-stressed or non-heat-stressed ova after culture at 38.5 or $41.0^{\circ} \mathrm{C}$ was evaluated by using a randomized block design with a split plot in PROC GLIMMIX. Preplanned comparisons were performed by using orthogonal contrasts.

\section{RESULTS}

\section{Use of Developmentally Competent Ova}

Culture of $\mathrm{COC}$ at $41.0^{\circ} \mathrm{C}$ did not alter the proportion of $\mathrm{PZ}$ recovered or those that had visibly lysed after denuding the associated cumulus and spermatozoa 
Table 1. Embryo development after otherwise developmentally competent ova underwent in vitro maturation (IVM) at 38.5 or $41^{\circ} \mathrm{C}^{1}$

\begin{tabular}{|c|c|c|c|c|c|c|c|c|c|c|}
\hline $\begin{array}{l}\text { IVM } \\
\text { temperature, }{ }^{\circ} \mathrm{C}\end{array}$ & $\begin{array}{l}\text { Total } \\
\text { COC }\end{array}$ & \multicolumn{2}{|c|}{13 to $17 \mathrm{hpi}$} & \multicolumn{4}{|c|}{ Cleavage, 69 to $72 \mathrm{hpi}$} & \multicolumn{3}{|c|}{ Compaction, 138 to $144 \mathrm{hpi}$} \\
\hline 41.0 & 4,576 & 94.0 & 8.1 & 66.8 & 11.8 & 37.3 & $50.6^{\mathrm{B}}$ & $23.4^{\mathrm{B}}$ & $34.6^{\mathrm{B}}$ & $60.7^{\mathrm{B}}$ \\
\hline SEM & & 1.7 & 0.7 & 2.4 & 1.2 & 1.4 & 1.9 & 1.6 & 2.0 & 3.0 \\
\hline$P$-value & & 0.24 & 0.22 & 0.19 & 0.09 & 0.09 & 0.01 & 0.0005 & 0.02 & 0.009 \\
\hline
\end{tabular}

A,B Means within a column differ.

${ }^{1} \mathrm{hpi}=$ hours post in vitro fertilization; COC $=$ cumulus-oocyte complex; PZ rcd = putative zygotes recovered; CM $=$ compact morulae.

${ }^{2}$ Relative to proportion cleaved.

(Table 1). The ability of ova to undergo cleavage after IVF was not altered by heat stress, yet the proportion of 8- to 16-cell-stage embryos was reduced $(P=0.01$; Table 1). At 138 to $144 \mathrm{~h}$ after IVF, fewer embryos from heat-stressed ova had undergone compaction (23.4 vs. $29.6 \% ; P=0.0005$; Table 1). Although proportionately fewer, the mean quality score of compact morulae from heat-stressed ova was equivalent to that from non-heatstressed ova (2.1 and 2.1; $P=0.75 ; \mathrm{SEM}=0.04$ ).

Culture of compact morulae from non-heat-stressed ova at $41.0^{\circ} \mathrm{C}$ was without a negative consequence on development or on the stage or quality of resulting blastocysts (Figure 2; treatment a vs. b). Moreover, when cultured at $38.5^{\circ} \mathrm{C}$, compact morulae from heat-stressed ova underwent blastocyst development and were similar in stage and quality to those from non-heat-stressed ova (Figure 2; treatment c vs. a, b). Nonetheless, if compact morulae from heat-stressed ova were exposed to $41.0^{\circ} \mathrm{C}$ for $12 \mathrm{~h}$, fewer underwent blastocyst development $(62.3$ vs. $71.9,71.5$, and $68.2 ; \mathrm{SEM}=3.1$; Figure 2 ; treatment d vs. a, b, c; $P=0.007)$. This effect was coincident with an increased proportion of degenerate embryos (treatment d vs. a, b, c; 26.9 vs. 17.9, 21.6, and $22.6 \%$; SEM $=3.3 ; P=0.03$ ). Although quality scores were not influenced by treatment, the numerical stage of blastocysts was greater for those from compact morulae cultured at $41.0^{\circ} \mathrm{C}$ and originating from heatstressed ova (6.4 vs. 6.3, 6.2, and 6.3; $\mathrm{SEM}=0.06$; Figure 2; treatment d vs. a, b, c; $P=0.04)$.

\section{Use of Developmentally Challenged Ova}

Culture of COC at $41.0^{\circ} \mathrm{C}$ did not alter the proportion of PZ recovered or those that had visibly lysed after denuding the associated cumulus and spermatozoa (Table 2 ). The ability of ova to undergo cleavage after IVF was not altered by heat stress; however, the proportion of 8- to 16-cell-stage embryos was reduced $(P=0.03$; Table 2). At 138 to $144 \mathrm{~h}$ after IVF, compaction rate of embryos from heat-stressed and non-heat-stressed ova was similar (Table 2). Quality scores of compact morulae from ova matured at 38.5 or $41.0^{\circ} \mathrm{C}$ did not differ (2.0 and 1.9; SEM $=0.1 ; P=0.28)$.

Exposure of compact morulae from non-heat-stressed ova to $41.0^{\circ} \mathrm{C}$ for $12 \mathrm{~h}$ reduced blastocyst development (66.6 vs. $51.6 \%$; $\mathrm{SEM}=6.0$ ) if embryos were from developmentally challenged ova (Figure 3 ; treatment a vs. b; $P=0.02$ ). This effect was coincident with an increased proportion of degenerate embryos (21.3 vs. $41.7 \%$; SEM $=6.4 ; P=0.001)$. Blastocyst develop-

Table 2. Embryo development after otherwise developmentally challenged ova underwent in vitro maturation (IVM) at 38.5 or $41^{\circ} \mathrm{C}^{1}$

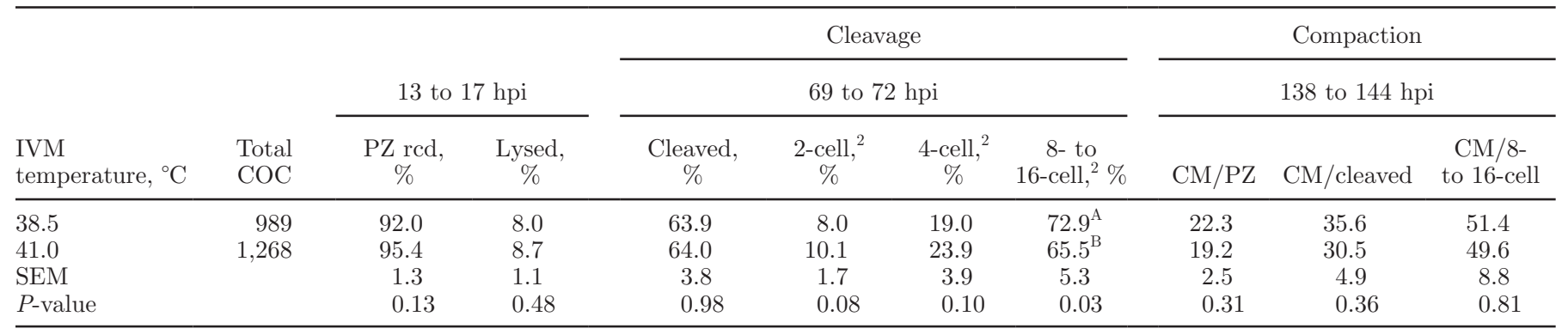

${ }_{\mathrm{A}, \mathrm{B}}$ Means within a column differ.

${ }^{1}$ hpi $=$ hours post in vitro fertilization; COC $=$ cumulus-oocyte complex; PZ rcd = putative zygotes recovered; CM $=$ compact morulae.

${ }^{2}$ Relative to proportion cleaved. 
ment of compact morulae from heat-stressed ova was not different from that of non-heat-stressed ova (Figure 3 ; treatment c vs. a, b: 58.4 vs. 66.6 and $51.1 \%$; SEM $=$ 5.0 and treatment d vs. a, b, c: 57.1 vs. $66.6,51.1$, and $58.4 \%$; SEM $=5.0$ ). Regardless of treatment, both the stage and quality of resulting blastocysts were similar (Figure 3).

\section{DISCUSSION}

This study demonstrated that the consequences of heat stress during the first $12 \mathrm{~h}$ of oocyte maturation go beyond the obvious effect of reducing blastocyst development, to include perturbations that carry over to otherwise morphologically normal embryos, increasing their susceptibility to environmental heat stress. To this end, culture of compact morulae from heat-stressed ova at $41.0^{\circ} \mathrm{C}$ reduced blastocyst development. Because this study and others have demonstrated this embryonic stage to be tolerant of in vivo (rectal temperatures $\geq 41.0^{\circ} \mathrm{C}$; Ealy et al., 1993$)$ and in vitro $\left(41.0^{\circ} \mathrm{C}\right.$; Ealy et al., 1995; Edwards and Hansen, 1997) heat stress, this finding was not expected. These findings indicate that although a subset of embryos from heat-stressed ova are capable of developing to more advanced stages and may appear morphologically normal, developmental competence is not equivalent to embryos from nonheat-stressed ova.

Although the underlying mechanisms remain unclear, the results may have been a consequence of fertilizing an "aged" ovum. For example, it was shown that heat-stress exposure during the first $12 \mathrm{~h}$ of maturation hastens developmentally important processes (Edwards et al., 2005) sufficient to shift developmental

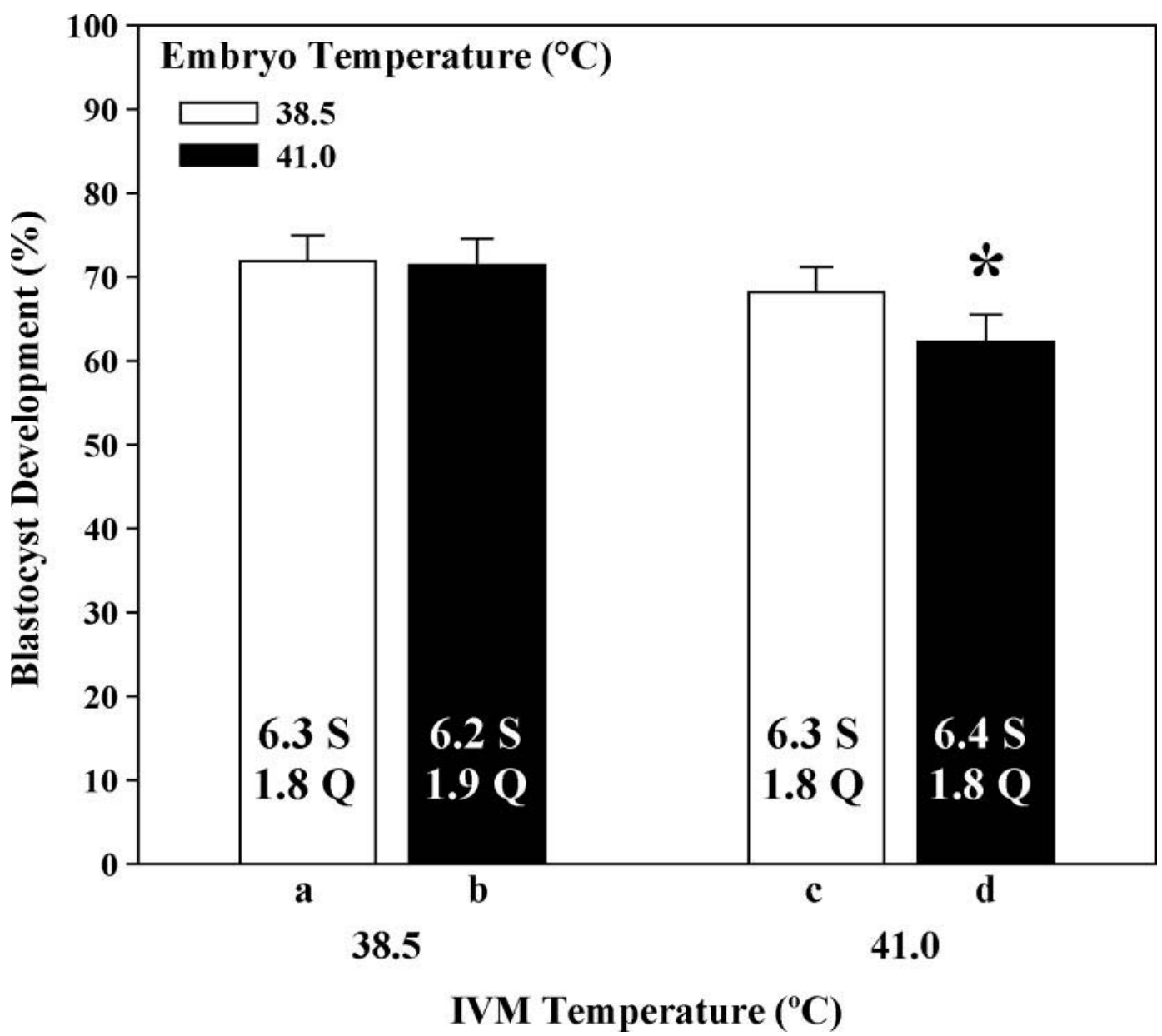

Figure 2. Thermolability of compact morulae from developmentally competent ova undergoing in vitro maturation (IVM) at 38.5 or $41.0^{\circ} \mathrm{C}$. Compact morulae were kept separate according to origin (i.e., IVM at 38.5 or $41.0^{\circ} \mathrm{C}$ ), then cultured at 38.5 or $41.0^{\circ} \mathrm{C}$, yielding 4 treatment combinations: a $(\mathrm{n}=297), \mathrm{b}(\mathrm{n}=303), \mathrm{c}(\mathrm{n}=358)$, and $\mathrm{d}(\mathrm{n}=361)$. Blastocyst development, stage $(\mathrm{S})$ and quality $(\mathrm{Q})$ were assessed. Preplanned orthogonal contrasts were performed as follows: 1 ) treatment a vs. b; blastocyst $P=0.91$, stage $P=0.44$, quality $P=0.15 ; 2)$ treatment c vs. a, b; blastocyst $P=0.26$, stage $P=0.13$, quality $P=0.50$; and 3 ) treatment d vs. a, b, c; blastocyst $P=0.007$, stage $P=0.04$, quality $P=$ 0.49. Stage SEM $=0.06$; quality $\mathrm{SEM}=0.06$. An asterisk $(*)$ denotes significance. 


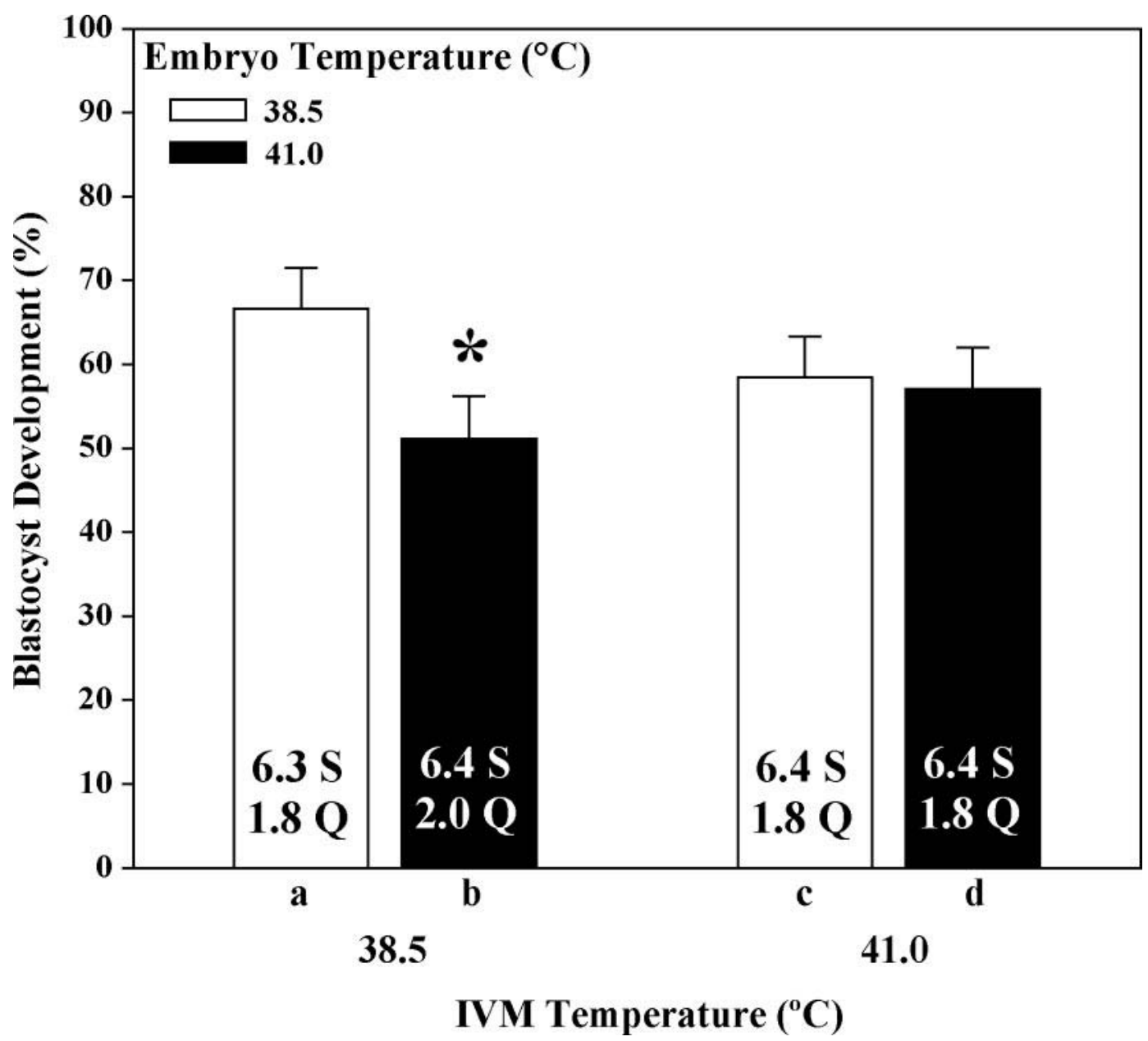

Figure 3. Thermolability of compact morulae from developmentally challenged ova undergoing in vitro maturation (IVM) at 38.5 or $41.0^{\circ} \mathrm{C}$ Compact morulae were kept separate according to origin (i.e., IVM at 38.5 or $41.0^{\circ} \mathrm{C}$ ), then cultured at 38.5 or $41.0^{\circ} \mathrm{C}$, yielding 4 treatment combinations: a $(\mathrm{n}=78), \mathrm{b}(\mathrm{n}=96), \mathrm{c}(\mathrm{n}=98)$, and $\mathrm{d}(\mathrm{n}=97)$. Blastocyst development, stage $(\mathrm{S})$ and quality $(\mathrm{Q})$ were assessed. Preplanned orthogonal contrasts were performed as follows: 1 ) treatment a vs. b; blastocyst $P=0.02$, stage $P=0.82$, quality $P=0.18 ; 2$ ) treatment c vs. a, b; $P=0.88$, stage $P=0.55$, quality $P=0.65$; and 3) treatment d vs. a, b, c; blastocyst $P=0.67$, stage $P=0.72$, quality $P=0.88$. Stage $\mathrm{SEM}=0.1$; quality $\mathrm{SEM}=0.1$. An asterisk $(*)$ denotes significance.

responsiveness by as much as $7.3 \mathrm{~h}$ (Schrock et al., 2007). Furthermore, like heat stress, the consequences of fertilizing an aged ovum include reduced blastocyst development (Ward et al., 2002), maternal transcripts, and synthesis of intracellular proteins (Xu et al., 1997). In some cases, sperm penetration and apoptosis (Tarin et al., 2000) may be problematic. Although the fate of morphologically normal embryos from heat-stressed ova remains unclear, the consequences of impaired fetal development, increased incidence of disease, and increased mortality rate from aged ova warrant further investigation.

Because the matured ovum contributes half of its genetic material and $>99 \%$ of its cytoplasm to the zygote, it is intuitive for embryo quality to depend on ovum quality. Current findings support this view by illustrating disparate differences in the responsiveness to environmental heat stress of compact morulae from developmentally competent compared with challenged ova. Specifically, exposure of compact morulae from non-heat-stressed ova to $41.0^{\circ} \mathrm{C}$ reduced blastocyst development by $23.3 \%$ if embryos were from developmentally challenged ova. In contrast, these findings were not observed if compact morulae were from developmentally competent ova. Although difficult to explain, differences related to genotype, physiological status of individual donors, technical factors, and yet other unidentified factors likely contribute to occasions when abattoir-derived ova matured at $38.5^{\circ} \mathrm{C}$ are developmentally challenged (i.e., yield less than the expected 20 to $50 \%$ blastocyst development after performing IVM-IVF-in vitro culture; Moore and Thatcher, 2006). 
Nonetheless, the increased susceptibility of morphologically normal embryos from heat-stressed or otherwise developmentally challenged ova emphasizes the importance of efforts to minimize stress exposure during maturation, particularly when the expectation is to obtain developmentally competent embryos.

Data showing that fewer heat-stressed ova underwent compaction after fertilization is another novel finding. Because compaction is requisite for blastocoel formation, this may explain in part why fewer develop to the blastocyst stage. In support of this, compact morulae from heat-stressed ova, although proportionately fewer, were of normal morphology and underwent blastocyst development at a rate comparable to those from nonheat-stressed ova when cultured in thermoneutral conditions. Furthermore, components important for compaction are present in the maturing ovum (i.e., mRNA for E-cadherin and $\beta$-catenin; Nganvongpanit et al., 2006) when the negative effects of heat stress are most noted (Edwards and Hansen, 1996).

Heat-induced reductions in embryonic development as a consequence of applying heat stress to maturing ova have seldom been associated with an overall reduction in cleavage rate (Lawrence et al., 2004; Edwards et al., 2005; Schrock et al., 2007). Rather, this study and that of Lawrence et al. (2004) noted that the proportion of cleaved embryos from heat-stressed ova that progressed to the 8- to 16-cell stage by 69 to 75 hpi was lower. Although not always repeated (Edwards et al., 2005; Schrock et al., 2007), an effect of heat stress in this study to retard early cleavage divisions was consistent with possible heat-induced perturbations in cell-cycle (LaRosa and Downs, 2007) and cytoskeletal (Roth and Hansen, 2005) components. The extent to which this finding contributed to reduced compaction rates of heat-stressed ova remains unclear. Nonetheless, the general effects of heat stress to perturb ovum components (Edwards and Hansen, 1997; Roth and Hansen, 2004; Edwards et al., 2005) attests to the complexity of the current and future challenges for identifying underlying mechanisms.

\section{CONCLUSIONS}

Efforts to gain a better understanding of the basic mechanisms through which heat stress compromises the ovum are important steps toward the development of practical solutions to ameliorate heat-induced infertility related to reduced ovum quality. In this regard, the consequences of exposing maturing ova to heat stress go beyond obvious effects to reduce development, but carry over to otherwise morphologically normal embryos to increase their susceptibility to heat stress. Thermolability of the few embryos that do develop from heat-stressed or otherwise developmentally challenged ova emphasizes the importance of minimizing exposure to stressor(s) during maturation, particularly if the intent is to obtain developmentally competent embryos for transfer into heat-stressed dairy cows for improving fertility.

\section{ACKNOWLEDGMENTS}

This research was supported in part by National Research Initiative Competitive Grant No. 2004-3520314772 from the USDA Cooperative State Research, Education, and Extension Service (Washington, DC), USDA Hatch Funds, the state of Tennessee through the Tennessee Agricultural Experiment Station, and the Department of Animal Science. Appreciation is extended to R. Payton, F. Scenna, G. Schrock, A. Ward, T. Wilson, and R. Harris for technical assistance associated with conducting experiment.

\section{REFERENCES}

Armstrong, D. V. 1994. Heat stress interaction with shade and cooling. J. Dairy Sci. 77:2044-2050.

Biggers, J. D., L. K. McGinnis, and M. Raffin. 2000. Amino acids and preimplantation development of the mouse in protein-free potassium simplex optimized medium. Biol. Reprod. 63:281293

Ealy, A. D., M. Drost, and P. J. Hansen. 1993. Developmental changes in embryonic resistance to adverse effects of maternal heat stress in cows. J. Dairy Sci. 76:2899-2905.

Ealy, A. D., J. L. Howell, V. H. Monterroso, C. F. Arechiga, and P. J. Hansen. 1995. Developmental changes in sensitivity of bovine embryos to heat shock and use of antioxidants as thermoprotectants. J. Anim. Sci. 73:1401-1407.

Edwards, J. L., and P. J. Hansen. 1996. Elevated temperature increases heat shock protein 70 synthesis in bovine two-cell embryos and compromises function of maturing oocytes. Biol. Reprod. 55:340 346.

Edwards, J. L., and P. J. Hansen. 1997. Differential responses of bovine oocytes and preimplantation embryos to heat shock. Mol. Reprod. Dev. 46:138-145.

Edwards, J. L., A. M. Saxton, J. L. Lawrence, R. R. Payton, and J. R. Dunlap. 2005. Exposure to a physiologically relevant elevated temperature hastens in vitro maturation in bovine oocytes. J. Dairy Sci. 88:4326-4333.

Gwazdauskas, F. C., W. W. Thatcher, and C. J. Wilcox. 1973. Physiological, environmental, and hormonal factors at insemination which may affect conception. J. Dairy Sci. 56:873-877.

LaRosa, C., and S. M. Downs. 2007. Meiotic induction by heat stress in mouse oocytes: Involvement of AMP-activated protein kinase and MAPK family members. Biol. Reprod. 76:476-486.

Lawrence, J. L., R. R. Payton, J. D. Godkin, A. M. Saxton, F. N. Schrick, and J. L. Edwards. 2004. Retinol improves development of bovine oocytes compromised by heat stress during maturation. J. Dairy Sci. 87:2449-2454.

Littell, R. C., G. A. Milliken, W. W. Stroup, R. D. Wolfinger, and O. Schabenberger. 2006. SAS System for Mixed Models. 2nd ed. SAS Inst. Inc., Cary, NC.

Livingston, T., D. Eberhardt, J. L. Edwards, and J. Godkin. 2004. Retinol improves bovine embryonic development in vitro. Reprod. Biol. Endocrinol. 2:83.

Monty, D. E. Jr., and L. K. Wolff. 1974. Summer heat stress and reduced fertility in Holstein-Friesian cows in Arizona. Am. J. Vet. Res. 35:1495-1500. 
Moore, K., and W. W. Thatcher. 2006. Major advances associated with reproduction in dairy cattle. J. Dairy Sci. 89:1254-1266.

Nganvongpanit, K., H. Muller, F. Rings, M. Gilles, D. Jennen, M. Holker, E. Tholen, K. Schellander, and D. Tesfaye. 2006. Targeted suppression of E-cadherin gene expression in bovine preimplantation embryo by RNA interference technology using double-stranded RNA. Mol. Reprod. Dev. 73:153-163.

Parrish, J. J., J. Susko-Parrish, M. A. Winer, and N. L. First. 1988. Capacitation of bovine sperm by heparin. Biol. Reprod. 38:11711180.

Payton, R. R., R. Romar, P. Coy, A. M. Saxton, J. L. Lawrence, and J. L. Edwards. 2004. Susceptibility of bovine germinal vesicle-stage oocytes from antral follicles to direct effects of heat stress in vitro. Biol. Reprod. 71:1303-1308.

Putney, D. J., S. Mullins, W. W. Thatcher, M. Drost, and T. S. Gross. 1989. Embryonic development in superovulated dairy cattle exposed to elevated ambient temperatures between the onset of estrus and insemination. Anim. Reprod. Sci. 19:37-51.

Robertson, I., and R. E. Nelson. 1998. Certification and identification of the embryo. Pages 103-107 in Manual of the International Embryo Transfer Society. 3rd ed. D. A. Stringfellow and S. M. Seidel, ed. Int. Embryo Transfer Soc., Savoy, IL.

Roman-Ponce, H., W. W. Thatcher, D. E. Buffington, C. J. Wilcox, and H. H. Van Horn. 1977. Physiological and production responses of dairy cattle to a shade structure in a subtropical environment. J. Dairy Sci. 60:424-430.

Roth, Z., and P. J. Hansen. 2004. Involvement of apoptosis in disruption of developmental competence of bovine oocytes by heat shock during maturation. Biol. Reprod. 71:1898-1906.
Roth, Z., and P. J. Hansen. 2005. Disruption of nuclear maturation and rearrangement of cytoskeletal elements in bovine oocytes exposed to heat shock during maturation. Reproduction 129:235-244.

Rutigliano, H. M., F. S. Lima, R. L. A. Cerri, L. F. Greco, J. M. Vilela, V. Magalhaes, F. T. Silvestre, W. W. Thatcher, and J. E. P. Santos. 2008. Effects of method of presynchronization and source of selenium on uterine health and reproduction in dairy cows. J. Dairy Sci. 91:3323-3336.

Schrock, G. E., A. M. Saxton, F. N. Schrick, and J. L. Edwards. 2007. Early in vitro fertilization improves development of bovine ova heat stressed during in vitro maturation. J. Dairy Sci. 90:42974303 .

Stott, G. H., and R. J. Williams. 1962. Causes of low breeding efficiency in dairy cattle associated with seasonal high temperatures. J. Dairy Sci. 45:1369-1375.

Tarin, J. J., S. Perez-Albala, and A. Cano. 2000. Consequences on offspring of abnormal function in ageing gametes. Hum. Reprod. Update 6:532-549.

Ulberg, L. C., and P. J. Burfening. 1967. Embryo death resulting from adverse environment on spermatozoa or ova. J. Anim. Sci. 26:571-577.

Ward, F., B. Enright, D. Rizos, M. Boland, and P. Lonergan. 2002. Optimization of in vitro bovine embryo production: Effect of duration of maturation, length of gamete co-incubation, sperm concentration and sire. Theriogenology 57:2105-2117.

Xu, Z., A. Abbott, G. S. Kopf, R. M. Schultz, and T. Ducibella. 1997. Spontaneous activation of ovulated mouse eggs: Timedependent effects on M-phase exit, cortical granule exocytosis, maternal messenger ribonucleic acid recruitment, and inositol 1,4,5-triphosphate sensitivity. Biol. Reprod. 57:743-750. 